\title{
PENGARUH METODE BELAJAR AKTIF MODEL PENGAJARAN TERARAH DALAM MENINGKATKAN PRESTASI DAN PEMAHAMAN PELAJARAN PAI PADA SISWA KELAS I SD NEGERI 200403 PADANGSIDIMPUAN TAHUN PELAJARAN 2016/2017
}

\author{
HAFSAH RITONGA, S.Ag.
} NIP: 196207051982012002.

Email : hafsahritonga2@gmail.com

\begin{abstract}
abstrak
Ada kecenderungan dalam dunia pendidikan dewasa ini untuk kembali pada pemikiran bahwa anak akan belajar lebih baik jika lingkungan diciptakan secara alamiah. Belajar akan lebih bermakna jika anak "mengalami" sendiri apa yang dipelajarinya, bukan 'mengetahui'-nya. Pembelajaran yang berorientasi target penguasaan materi terbukti berhasil dalam kompetisi 'mengingat' jangka pendek, tetapi gagal dalam membekali anak memecahkan persoalan dalam kehidupan jangkan panjang.

Permasalahan yang ingin dikaji dalam penelitian ini adalah: (a) Bagaimanakah peningkatan prestasi belajar PAI dengan diterapkannya metode belajar aktif model pengajaran terarah? (b) Bagaimanakah pengaruh metode belajar aktif model pengajaran terarah terhadap motivasi belajar?

Tujuan dari penelitian ini adalah: (a) Ingin mengetahui peningkatan prestasi belajar PAI setelah diterapkannya metode belajar aktif model pengajaran terarah.(b) Ingin mengetahui pengaruh motivasi belajar PAI setelah diterapkan metode belajar aktif model pengajaran terarah.

Penelitian ini menggunakan penelitian tindakan (action research) sebanyak tiga putaran. Setian putaran terdiri dari empat tahap yaitu: rancangan, kegiatan dan pengamatan, refleksi, dan refisi. Sasaran penelitian ini adalh siswa kelas I. Data yang diperoleh berupa hasil tes formatif, lembar observasi kegiatan belajar mengajar.

Dari hasil analis didapatkan bahwa prestasi belajar siswa mengalami peningkatan dari siklus I sampai siklus III yaitu, siklus I (66,67\%), siklus II (77,78\%), siklus III $(88,89 \%)$.

Simpulan dari penelitian ini adalah metode belajar aktif model pengajaran terarah dapat berpengaruh positif terhadap motivasi belajar Siswa Kelas I, serta model pembelajaran ini dapat digunakan sebagai salah satu alternative pembelajaran PAI.
\end{abstract}

\section{PENDAHULUAN}

Dalam kegiatan belajar mengajar tidak semua anak didik mampu berkonsentrasi dalam waktu yang relatif lama. Daya serap anak didik terhadap bahan yang diberikan juga bermacammacam, ada yang cepat, ada yang sedang, dan ada yang lambat. Faktor intelegensi jawab, tetapi untuk sekelompok anak didik yang mempengaruhi daya serap anak didik terhadap lain mereka lebih mudah menyerap bahan bahan pelajaran yang diberikan oleh guru. Cepat pelajaran bila guru menggunakan metode lambatnya penerimaan anak didik terhadap bahan demonstrasi atau eksperimen.

pelajaran yang diberikan menghendaki pemberian waktu yang bervariasi, sehingga penguasaan penuh dapat tercapai.
Terhadap perbedaan daya serap anak didik sebagaimana tersebut di atas, memerlukan strategi pengajaran yang tepat. Metodelah salah satu jawabannya. Untuk sekelompok anak didik boleh jadi mereka mudah menyerap bahan pelajaran bila guru menggunakan metode tanya 
Karena itu dalam kegiatan belajar otak, mengkaji gagasan, memecahkan masalah, mengajar, menurut Roestiyah, N.K. (1989: 1), dan menerapkan apa yang mereka pelajari. guru harus memiliki strategi agar anak didik Belajar aktif harus gesit, menyenangkan, dapat belajar secara efektif dan efisien, mengena bersemangat dan penuh gairah. Siswa bahkan pada tujuan yang diharapkan. Salah satu langkah sering meninggalkan tempat duduk mereka, untuk memiliki strategi itu adalah harus bergerak leluasa dan berfikir keras (moving about menguasai teknik-teknik penyajian atau biasanya dan thinking aloud)

disebut metode mengajar. Dengan demikian, metode mengajar adalah stategi pengajaran sebagai alat untuk mencapai tujuan yang diharapkan.

Ada kecenderungan dalam dunia "m pendidikan dewasa ini untuk kembali pada pemikiran bahwa anak akan belajar lebih baik jika lingkungan diciptakan secara alamiah. Belajar akan lebih bermakna jika anak

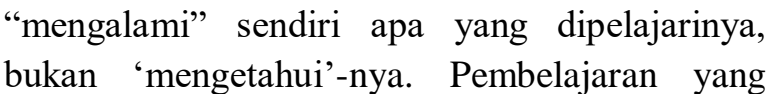
berorientasi target penguasaan materi terbukti berhasil dalam kompetisi 'mengingat' jangka pendek, tetapi gagal dalam membekali anak memecahkan persoalan dalam kehidupan jangkan panjang. Dan, itulah yang terjadi di kelas-kelas sekolah kita! Pendekatan kontekkstual (contextual teaching learning/CTL) adalah suatu pendekatan pengajaran yang dari karakteristiknya memenuhi harapan itu. Sekrang ini pengajaran kontekstual menjadi tumpuan harapan para ahli pendidikan dan pengajaran dalam upaya 'menghidupkan'kelas secara maksimal. Kelas yang 'hidup' diharapkan dapat mengimbangi perubahan yang terjadi di luar sekolah yang sedemikian cepat.

Mengajar bukan semata persoalan menceritakan. Belajar bukanlah konsekuensi otomatis dari perenungan informasi ke dalam benak siswa. Belajar memerlukan keterlibatan mental dan kerja siswa sendiri. Penjelasan dan pemeragaan semata tidak akan membuahkan hasil belajar yang langgeng. Yang bisa membuahkan hasil belajar yang langgeng hanyalah kegiatan belajar aktif.

Untuk bisa mempelajari sesuatu dengan baik, kita perlu mendengar, melihat, mengajukan pertanyaan tentangnya, dan membahasnya dengan orang lain. Bukan Cuma itu, siswa perlu "mengerjakannya", yakni menggambarkan sesuatu dengan cara mereka sendiri, menunjukkan contohnya, mencoba mempraktekkan keterampilan, dan mengerjakan tugas yang menuntut pengetahuan yang telah atau harus mereka dapatkan.

Setiap akan mengajar, guru perlu membuat persiapan mengajar dalam rangka melaksanakan sebagian dari rencana bulanan dan rencana tahunan. Dalam persiapan itu sudah terkandung tentang, tujuan mengajar, pokok yang akan diajarkan, metode mengajar, bahan pelajaran, alat peraga dan teknik evaluasi yang digunakan. Karena itu setiap guru harus memahami benar tentang tujuan mengajar, secara khusus memilih dan menentukan metode mengajar sesuai dengan tujuan yang hendak dicapai, cara memilih, menentukan dan menggunakan alat peraga, cara membuat tes dan menggunakannya, dan pengetahuan tentang alat-alat evalasi.

Sementara itu teknologi pembelajaran adalah salah satu dari aspek tersebut yang cenderung diabaikan oleh beberapa pelaku pendidikan, terutama bagi mereka yang menganggap bahwa sumber daya manusia pendidikan, sarana dan prasarana pendidikanlah yang terpenting. Padahal kalau dikaji lebih lanjut, setiap pembelajaran pada semua tingkat pendidikan baik formal maupun non formal apalagi tingkat Sekolah Dasar, haruslah berpusat pada kebutuhan perkembangan anak sebagai

Apa yang menjadikan belajar aktif? Agar calon individu yang unik, sebagai makhluk belajar menjadi aktif siswa harus mengerjakan sosial, dan sebagai calon manusia Indonesia. banyak sekali tugas. Mereka harus menggunakan 
Hal tersebut dapat dicapai apabila dalam tingkat kontekstual berbasis masalah antara aktivitas belajar mengajar, guru senantiasa pelaku peneliti dan peneliti dari luar, (3) proses memanfaatkan teknologi pembelajaran yang yang digunakan dalam melakukan penelitian, dan mengacu pada pembelajaran struktural dalam (4) hubungan antara proyek dengan sekolah. penyampaian materi dan mudah diserap peserta didik atau siswa berbeda.

Dalam penelitian ini menggunakan bentuk Khususnya dalam pembelajaran berperan sekali dalam proses penelitian tindakan Pendidikan Agama Islam, agar siswa dapat kelas. Dalam bentuk ini, tujuan utama penelitian memahami materi yang disampaikan guru dengan tindakan kelas ialah untuk meningkatkan praktikbaik, maka proses pembelajaran kontektual, guru praktik pembelajaran di kelas. Dalam kegiatan akan memulai membuka pelajaran dengan ini, guru terlibat langsung secara penuh dalam menyampaikan kata kunci, tujuan yang ingin proses perencanaan, tindakan, observasi, dan dicapai, baru memaparkan isi dan diakhiri dengan refleksi. Kehadiran pihak lain dalam penelitian memberikan soal-soal kepada siswa.

Dengan menyadari gejala-gejala atau kenyataan tersebut diatas, maka dalam penelitian ini penulis mengambil judul "Pengaruh Metode Belajar Aktif Model Pengajaran Terarah Dalam Meningkatkan Prestasi Dan Pemahaman Pelajaran PAI Pada Siswa Kelas I SD NEGERI 200403 Padangsidimpuan Tahun Pelajaran 2016/2017."

\section{METODOLOGI PENELITIAN}

Penelitian ini merupakan penelitian tindakan (action research), karena penelitian dilakukan untuk memecahkan masalah pembelajaran di kelas. Penelitian ini juga termasuk penelitian deskriptif, sebab menggambarkan bagaimana suatu teknik pembelajaran diterapkan dan bagaimana hasil yang diinginkan dapat dicapai.

Menurut Sukidin dkk (2002:54) ada 4 macam bentuk penelitian tindakan, yaitu: (1) penelitian tindakan guru sebagai peneliti, (2) penelitian tindakan kolaboratif, (3) penelitian tindakan simultan terintegratif, dan (4) penelitian tindakan sosial eksperimental.

Keempat bentuk penelitian tindakan di atas, ada persamaan dan perbedaannya. Menurut Oja dan Smulyan sebagaimana dikutip oleh Kasbolah, (2000) (dalam Sukidin, dkk. 2002:55), ciri-ciri dari setiap penelitian tergantung pada: (1) tujuan utamanya atau pada tekanannya, (2) ini peranannya tidak dominan dan sangat kecil.

Penelitian ini mengacu pada perbaikan pembelajaran yang berkesinambungan. Kemmis dan Taggart (1988:14) menyatakan bahwa model penelitian tindakan adalah berbentuk spiral. Tahapan penelitian tindakan pada suatu siklus meliputi perencanaan atau pelaksanaan observasi dan refleksi. Siklus ini berlanjut dan akan dihentikan jika sesuai dengan kebutuhan dan dirasa sudah cukup.

\section{HASIL PENELITIAN DAN PEMBAHASAN}

$\begin{array}{llr}\text { A. Hubungan Pembelajaran } & \text { Model } \\ \text { Kontekstual berbasis masalah } & \text { dengan } \\ \text { Ketuntasan Belajar } & & \end{array}$

Suatu pokok bahasan atau sub pokok bahasan dianggap tuntas secara klasikal jika siswa yang mendapat nilai 65 lebih dari atau sama dengan $85 \%$, sedangkan seorang siswa dinyatakan tuntas belajar pada pokok bahasan atau sub pokok bahasan tertentu jika mendapat nilai minimal 65.

1. Siklus I

a. Tahap Perencanaan

Pada tahap ini peneliti
mempersiapkan perangkat
pembelajaran yang terdiri dari
rencana pelajaran 1, soal tes formatif
1 dan alat-alat pengajaran yang


mendukung. Selain itu juga dipersiapkan lembar observasi pengelolaan model pembelajaran Kontekstual Berbasis Masalah, dan lembar observasi aktivitas guru dan siswa.

b. Tahap Kegiatan dan Pelaksanaan

Pelaksanaan kegiatan belajar mengajar untuk siklus I dilaksanakan pada tanggal 4 September 2017 di Kelas I jumlah siswa 29 siswa. Dalam hal ini peneliti bertindak sebagai pengajar. Adapun proses belajar mengajar mengacu pada rencana pelajaran yang telah dipersiapkan. Pengamatan (observasi) dilaksanakan bersamaan dengan pelaksanaan belajar mengajar.

Pada akhir proses belajar mengajar siswa diberi tes formatif I dengan tujuan untuk mengetahui tingkat keberhasilan siswa dalam proses belajar mengajar yang telah dilakukan. Adapun data hasil penelitian pada siklus I adalah sebagai berikut.

Tabel 4.1. Rekapitulasi Hasil Tes Formatif Siswa Pada Siklus I

\begin{tabular}{|c|l|c|}
\hline No & \multicolumn{1}{|c|}{ Uraian } & $\begin{array}{c}\text { Hasil } \\
\text { Siklus I }\end{array}$ \\
\hline 1 & $\begin{array}{l}\text { Nilai rata-rata tes } \\
\text { formatif }\end{array}$ & 70,00 \\
3 & $\begin{array}{l}\text { Jumlah siswa yang } \\
\text { tuntas belajar } \\
\text { Persentase ketuntasan } \\
\text { belajar }\end{array}$ & 68,18 \\
\hline
\end{tabular}

Dari tabel di atas dapat dijelaskan bahwa dengan menerapkan pembelajaran model
Kontekstual berbasis masalah diperoleh nilai rata-rata prestasi belajar siswa adalah 70,00 dan ketuntasan belajar mencapai $68,18 \%$ atau ada 15 siswa dari 29 siswa sudah tuntas belajar. Hasil tersebut menunjukkan bahwa pada siklus pertama secara klasikal siswa belum tuntas belajar, karena siswa yang memperoleh nilai $\geq 65$ hanya sebesar $68,18 \%$ lebih kecil dari persentase ketuntasan yang dikehendaki yaitu sebesar $85 \%$. Hal ini disebabkan karena siswa masih merasa baru dan belum mengerti apa yang dimaksudkan dan digunakan guru dengan menerapkan pembelajaran model Kontekstual berbasis masalah.

c. Refleksi

Dalam pelaksanaan kegiatan belajar mengajar diperoleh informasi dari hasil pengamatan sebagai berikut:

1) Guru kurang maksimal dalam memotivasi siswa dan dalam menyampaikan tujuan pembelajaran

2) Guru kurang maksimal dalam pengelolaan waktu

3) Siswa kurang aktif selama d. Refisi pembelajaran berlangsung

Pelaksanaan kegiatan belajar mengajar pada siklus I ini masih terdapat kekurangan, sehingga perlu adanya revisi untuk dilakukan pada siklus berikutnya.

1) Guru perlu lebih terampil dalam memotivasi siswa dan lebih jelas dalam menyampaikan tujuan pembelajaran. Dimana siswa diajak untuk terlibat langsung dalam setiap kegiatan yang akan dilakukan.

2) Guru perlu mendistribusikan waktu secara baik dengan 
menambahkan informasi- Tabel 4.2. Rekapitulasi Hasil Tes Formatif Siswa informasi yang dirasa perlu dan Pada Siklus II memberi catatan.

3) Guru harus lebih terampil dan bersemangat dalam memotivasi siswa sehingga siswa bisa lebih antusias.

2. Siklus II

a. Tahap perencanaan

Pada tahap ini peneliti
mempersiapkan perangkat
pembelajaran yang terdiri dari
rencana pelajaran 2, soal tes formatif
2 dan alat-alat pengajaran yang
mendukung.

b. Tahap kegiatan dan pelaksanaan

Pelaksanaan kegiatan belajar mengajar untuk siklus II dilaksanakan pada tanggal 11 September 2017 di Kelas I dengan jumlah siswa 29 siswa. Dalam hal ini peneliti bertindak sebagai pengajar. Adapun proses belajar mengajar mengacu pada rencana pelajaran dengan memperhatikan revisi pada siklus I, sehingga kesalahan atau kekurangan pada siklus I tidak terulang lagi pada siklus II. Pengamatan (observasi) dilaksanakan bersamaan dengan pelaksanaan belajar mengajar.

Pada akhir proses belajar mengajar siswa diberi tes formatif II dengan tujuan untuk mengetahui tingkat keberhasilan siswa dalam proses belajar mengajar yang telah dilakukan. Instrumen yang digunakan adalah tes formatif II. Adapun data hasil penelitian pada siklus II adalah sebagai berikut.

\begin{tabular}{|c|l|c|}
\hline No & \multicolumn{1}{|c|}{ Uraian } & Hasil Siklus II \\
\hline 1 & $\begin{array}{l}\text { Nilai rata-rata tes } \\
\text { formatif }\end{array}$ & 77,73 \\
2 & $\begin{array}{l}\text { Jumlah siswa yang } \\
\text { tuntas belajar } \\
\text { Persentase } \\
\text { ketuntasan belajar }\end{array}$ & 79,01 \\
\hline
\end{tabular}

Dari tabel di atas diperoleh nilai rata-rata prestasi belajar siswa adalah 77,73 dan ketuntasan belajar mencapai $79,01 \%$ atau ada 17 siswa dari 29 siswa sudah tuntas belajar. Hasil ini menunjukkan bahwa pada siklus II ini ketuntasan belajar secara klasikal telah mengalami peningkatan sedikit lebih baik dari siklus I. Adanya peningkatan hasil belajar siswa ini karena setelah guru menginformasikan bahwa setiap akhir pelajaran akan selalu diadakan tes sehingga pada pertemuan berikutnya siswa lebih termotivasi untuk belajar. Selain itu siswa juga sudah mulai mengerti apa yang dimaksudkan dan diinginkan guru dengan menerapkan pembelajaran model Kontekstual berbasis masalah

\section{c. Refleksi}

Dalam pelaksanaan kegiatan belajar diperoleh informasi dari hasil pengamatan sebagai berikut.

1) Memotivasi siswa

2) Membimbing siswa merumuskan kesimpulan/menemukan konsep

3) Pengelolaan waktu

d. Revisi Rancangan

Pelaksanaan kegiatan belajar pada siklus II ini masih terdapat kekurangan-kekurangan. Maka perlu adanya revisi untuk dilaksanakan pada siklus II antara lain: 
1) Guru dalam memotivasi siswa hendaknya dapat membuat siswa lebih termotivasi selama proses belajar mengajar berlangsung.

2) Guru harus lebih dekat dengan siswa sehingga tidak ada perasaan takut dalam diri siswa baik untuk mengemukakan pendapat atau bertanya.

3) Guru harus lebih sabar dalam membimbing siswa merumuskan kesimpulan/menemukan konsep.

4) Guru harus mendistribusikan waktu secara baik sehingga kegiatan pembelajaran dapat berjalan sesuai dengan yang diharapkan.

5) Guru sebaiknya menambah lebih banyak contoh soal dan memberi soal-soal latihan pada siswa untuk dikerjakan pada setiap kegiatan belajar mengajar.

3. Siklus III

a. Tahap perencanaan

Pada tahap ini peneliti mempersiapkan perangkat pembelajaran yang terdiri dari rencana pelajaran 3 , soal tes formatif 3 dan alat-alat pengajaran yang mendukung.

b. Tahap kegiatan dan pengamatan

Pelaksanaan kegiatan belajar mengajar untuk siklus III dilaksanakan pada tanggal 18 September 2017 di Kelas I dengan jumlah siswa 29 siswa. Dalam hal ini peneliti bertindak sebagai pengajar. Adapun proses belajar mengajar mengacu pada rencana pelajaran dengan memperhatikan revisi pada siklus II, sehingga kesalahan atau kekurangan pada siklus II tidak terulang lagi pada siklus III. Pengamatan (observasi) dilaksanakan bersamaan dengan pelaksanaan belajar mengajar.
Pada akhir proses belajar mengajar siswa diberi tes formatif III dengan tujuan untuk mengetahui tingkat keberhasilan siswa dalam proses belajar mengajar yang telah dilakukan. Instrumen yang digunakan adalah tes formatif III. Adapun data hasil penelitian pada siklus III adalah sebagai berikut.

Tabel 4.3. Hasil Formatif Siswa Pada Siklus III

\begin{tabular}{|c|l|c|}
\hline No & \multicolumn{1}{|c|}{ Uraian } & $\begin{array}{c}\text { Hasil } \\
\text { Siklus } \\
\text { III }\end{array}$ \\
\hline 1 & $\begin{array}{l}\text { Nilai rata-rata tes } \\
\text { formatif }\end{array}$ & 82,73 \\
3 & $\begin{array}{l}\text { Jumlah siswa yang } \\
\text { tuntas belajar } \\
\text { Persentase } \\
\text { ketuntasan belajar }\end{array}$ & 86,36 \\
\hline
\end{tabular}

Berdasarkan tabel di atas diperoleh nilai rata-rata tes formatif sebesar 82,73 dan dari 29 siswa telah tuntas sebanyak 24 siswa dan 5 siswa belum mencapai ketuntasan belajar. Maka secara klasikal ketuntasan belajar yang telah tercapai sebesar $86,36 \%$ (termasuk kategori tuntas). Hasil pada siklus III ini mengalami peningkatan lebih baik dari siklus II. Adanya peningkatan hasil belajar pada siklus III ini dipengaruhi oleh adanya peningkatan kemampuan guru dalam menerapkan pembelajaran model Kontekstual berbasis masalah sehingga siswa menjadi lebih terbiasa dengan pembelajaran seperti ini sehingga siswa lebih mudah dalam memahami materi yang telah diberikan. 
c. Refleksi

Pada tahap ini akan dikaji apa yang telah terlaksana dengan baik maupun yang masih kurang baik dalam proses belajar mengajar dengan penerapan pembelajaran model Kontekstual berbasis masalah . Dari data-data yang telah diperoleh dapat diuraikan sebagai berikut:

1) Selama proses belajar mengajar guru telah melaksanakan semua pembelajaran dengan baik. Meskipun ada beberapa aspek yang belum sempurna, tetapi persentase pelaksanaannya untuk masing-masing aspek cukup besar.

2) Berdasarkan data hasil pengamatan diketahui bahwa siswa aktif selama proses belajar berlangsung.

3) Kekurangan pada siklus-siklus sebelumnya sudah mengalami perbaikan dan peningkatan sehingga menjadi lebih baik.

4) Hasil belajar siswa pada siklus III mencapai ketuntasan.

d. Revisi Pelaksanaan

Pada siklus III guru telah menerapkan pembelajaran model Kontekstual berbasis masalah dengan baik dan dilihat dari aktivitas siswa serta hasil belajar siswa pelaksanaan proses belajar mengajar sudah berjalan dengan baik. Maka tidak diperlukan revisi terlalu banyak, tetapi yang perlu diperhatikan untuk tindakan selanjutnya adalah memaksimalkan dan mempertahankan apa yang telah ada dengan tujuan agar pada pelaksanaan proses belajar mengajar selanjutnya penerapan model pengajaran kontekstual berbasis masalah dapat meningkatkan proses belajar mengajar sehingga tujuan pembelajaran dapat tercapai.
B. Pembahasan

1. Ketuntasan Hasil Belajar Siswa

Melalui hasil penelitian ini menunjukkan bahwa pembelajaran model Kontekstual berbasis masalah memiliki dampak positif dalam meningkatkan prestasi belajar siswa. Hal ini dapat dilihat dari semakin mantapnya pemahaman siswa terhadap materi yang disampaikan guru (ketuntasan belajar meningkat dari siklus I, II, dan III) yaitu masing-masing 68,18\%, 79,01\%, dan $86,36 \%$. Pada siklus III ketuntasan belajar siswa secara klasikal telah tercapai.

2. Kemampuan Guru dalam Mengelola Pembelajaran

Berdasarkan analisis data, diperoleh aktivitas siswa dalam proses belajar mengajar dengan menerapkan model pengajaran kontekstual berbasis masalah dalam setiap siklus mengalami peningkatan. Hal ini berdampak positif terhadap prestasi belajar siswa yaitu dapat ditunjukkan dengan meningkatnya nilai rata-rata siswa pad setiap siklus yang terus mengalami peningkatan.

3. Aktivitas Siswa Dalam Pembelajaran

Berdasarkan analisis data, diperoleh aktivitas siswa dalam proses pembelajaran PAI pada pokok bahasan Surah Al-Fatihah dengan model pengajaran kontekstual berbasis masalah yang paling dominan adalah, mendengarkan/memperhatikan

penjelasan guru, dan diskusi antar siswa/antara siswa dengan guru. Jadi dapat dikatakan bahwa aktivitas siswa dapat dikategorikan aktif.

Sedangkan untuk aktivitas guru selama pembelajaran telah melaksanakan langkah-langkah kegiatan belajar mengajar dengan menerapkan pengajaran 
konstekstual model pengajaran berbasis Arikunto, Suharsimi. 2001. Dasar-dasar Evaluasi masalah dengan baik. Hal ini terlihat dari aktivitas guru yang muncul di antaranya aktivitas membimbing dan mengamati siswa dalam menemukan konsep, menjelaskan materi yang sulit, memberi umpan balik/evaluasi/tanya jawab dimana prosentase untuk aktivitas di atas cukup besar.

\section{KESIMPULAN}

Berdasarkan hasil penelitian yang telah dipaparkan selama tiga siklus, hasil seluruh pembahasan serta analisis yang telah dilakukan dapat disimpulkan sebagai berikut:

1. Model pengajaran kontekstual berbasis masalah dapat meningkatkan kualitas pembelajaran PAI.

2. Pembelajaran Metode Belajar Aktif Model Pengajaran Terarah Dalam memiliki dampak positif dalam meningkatkan prestasi belajar siswa yang ditandai dengan peningkatan ketuntasan belajar siswa dalam setiap siklus, yaitu siklus I $(68,18 \%)$, siklus II $(79,01 \%)$, siklus III $(86,36 \%)$.

3. Model Metode Belajar Aktif Model Pengajaran Terarah Dalam dapat menjadikan siswa merasa dirinya mendapat perhatian dan kesempatan untuk menyampaikan pendapat, gagasan, ide dan pertanyaan.

4. Siswa dapat bekerja secara mandiri maupun kelompok, serta mampu mempertanggungjawabkan segala tugas individu maupun kelompok.

5. Penerapan pembelajaran Metode Belajar Aktif Model Pengajaran Terarah Dalam, mempunyai pengaruh positif, yaitu dapat meningkatkan motivasi belajar siswa.

\section{DAFTAR PUSTAKA}

Ali, Muhammad. 1996. Guru Dalam Proses Belajar Mengajar. Bandung: Sinar Baru Algesindon.

Arikunto, Suharsimi. 1993. Manajemen Mengajar Secara Manusiawi. Jakarta: Rineksa Cipta.

Pendidikan. Jakarta: Bumi Aksara.

Arikunto, Suharsimi. 2002. Prosedur Penelitian

Suatu Pendekatan Praktek. Jakarta: Rineksa Cipta.

Azhar, Lalu Muhammad. 1993. Proses Belajar Mengajar Pendidikan. Jakarta: Usaha Nasional.

Daroeso, Bambang. 1989. Dasar dan Konsep Pendidikan Moral Pancasila. Semarang: Aneka Ilmu.

Djamarah, Syaiful Bahri. 2002. Strategi Belajar Mengajar. Jakarta: Rineksa Cipta.

Djamarah, Syaiful Bahri. 2002. Psikologi Belajar. Jakarta: Rineksa Cipta.

Hadi, Sutrisno. 1982. Metodologi Research, Jilid 1. Yogyakarta: YP. Fak. Psikologi UGM.

Hamalik, Oemar. 2002. Psikologi Belajar dan Mengajar. Bandung: Sinar Baru Algesindo.

Hasibuan K.K. dan Moerdjiono. 1998. Proses Belajar Mengajar. Bandung: Remaja Rosdakarya.

Margono. 1997. Metodologi Penelitian Pendidikan. Jakarta. Rineksa Cipta.

Masriyah. 1999. Analisis Butir Tes. Surabaya: Universitas Press.

Ngalim, Purwanto M. 1990. Psikologi Pendidikan. Bandung: PT. Remaja Rosdakarya.

Nur, Moh. 2001. Pemotivasian Siswa untuk Belajar. Surabaya: University Press. Univesitas Negeri Surabaya.

Rustiyah, N.K. 1991. Strategi Belajar Mengajar. Jakarta: Bina Aksara.

Sardiman, A.M. 1996. Interaksi dan Motivasi Belajar Mengajar. Jakarta: Bina Aksara.

Soekamto, Toeti. 1997. Teori Belajar dan Model Pembelajaran. Jakarta: PAU-PPAI, Universitas Terbuka.

Sukidin, dkk. 2002. Manajemen Penelitian Tindakan Kelas. Surabaya: Insan Cendekia.

Surakhmad, Winarno. 1990. Metode Pengajaran Nasional. Bandung: Jemmars.

Suryosubroto, B. 1997. Proses Belajar Mengajar di Sekolah. Jakarta: PT. Rineksa Cipta. 